\title{
Motivational beliefs among nontraditional prospective teachers from the United States: expectancies and values
}

Margareta M. Thomson, McClannon Julia 


\title{
Motivational beliefs among nontraditional prospective teachers from the United States: expectancies and values
}

\author{
Margareta M. Thomson ${ }^{a^{*}}$, Julia McClannon ${ }^{b}$ \\ ${ }^{a}$ Educational Psychology Program, North Carolina State University, Raleigh, North Carolina, 27695, United States \\ ${ }^{b}$ Fuquay-Varina High School, 201 Bengal Boulevard, Fuquay-Varina, North Carolina, 27526, United States \\ *Corresponding author: mmpop@ncsu.edu
}

\section{Abstract}

\section{Keywords:}

teacher education, motivations, values, expectancies, beliefs
The current study analyzed three prospective teachers' career path using an Expectancy-Value model. All participants were nontraditional college students, enrolled in a master's of teaching program (MAT) in the United States, and participated in an in-depth interview about their teaching goal. Study results summarize the commonalities and differences among participants using a cross-case study analysis. The major categories from participants' interviews were related to their expectancies (i.e., expectations, ability beliefs), attainment values (i.e., importance), intrinsic values (i.e., enjoyment), utility values (i.e., practical significance) and cost (i.e., time, money) about the teaching goal. Implications for teacher education and practice are discussed.
Zusammenfasung

Schlüsselwörter: Lehramstsstudium, Motivation, Werte, Erwartungen
Die vorliegende Studie analysiert die Laufbahn dreier Lehramtswärter mithilfe des Erwartung-mal-Wert-Modells. Die Teilnehmer sind nicht-traditionelle Studierende, die ein Master-Programm für Lehramt (MAT) in den Vereinigten Staaten belegt haben, und die an einem ausführlichen Interview über ihre beruflichen Ziele teilgenommen haben. Die Resultate fassen mithilfe der Cross-Case-Analyse Ähnlichkeiten und Unterschiede zwischen den Teilnehmern zusammen. Die Hauptkategorien aus den Teilnehmerbefragungen werden mit ihren beruflichen Erwartungen als Lehrer (z.B. Erwartungen, Selbstbewusstsein), Leistungswerte (z.B. Bedeutung), intrinsische Werte (z.B. Freude), Brauchbarkeitswert (z.B praktische Bedeutung) und Kosten (z.B. Zeit, Kosten) verbunden. Es wird deren Auswirkungen auf das Lehramtsstudium und den Beruf diskutiert.

\section{Introduction and Purpose}

Using an Expectancy-Value model (Wigfield \& Eccles, 2000) we analyzed in the current study nontraditional preservice teachers' (i.e., career switchers) motivations, expectations of the career, planned instruction and their views of the profession. Contributions from such research could lead to reforms in educator preparation programs as well as preparing more effective and committed teachers (Manuel \& Hughes, 2006). Since many of the teaching population among Australia, the United States, and several European countries are aging (Thomson \& Palermo, 2014; Thomson \& Palermo, 2018; Watt \& Richardson, 2007), research conducted now will be influential in policymaking, teacher training and recruitment for the future. If there are trends in motivations and expectancies, researchers can draw conclusions about those trends and give suggestions for teacher education programs in terms of recruitment of new students. Research on teacher motivation describes three main factors illustrating why teachers choose to teach: perceived benefits of the career or reasons why one would want to teach, perceived negative aspects of teaching or why one would not want to teach, and various other factors such as commentary on the profession, working conditions (Thomson, 2018; Thomson \& McIntyre, 2013; Thomson \& Palermo, 2014; Thomson \& Palermo, 2018). Common reasons listed for choosing the teacher career include the love for working with children, personal fulfillment, job security, having a calling to teach, and being able to influence others as a role model. Schutz et al. (2001) found several specific factors for joining the career, including altruistic motives, as has been already reported, past experiences, and past teachers. Other studies propose that people might join teaching due to their personal philosophies about education that teachers who feel a calling to the profession would be even more motivated to stay in teaching if they felt they could be recognized for their calling (Ashiedu \& Scott-Ladd, 2012; Backes \& Burns, 2008; Curtis, 2012). 
The purpose of the current study was to analyze individuals' motivations and views about teaching using an Expectancy-Value Theory (EVT) approach. Data from three case studies about pre-service teachers' motivations for teaching, expectancies about the teaching profession, and values for the teaching profession were analyzed. Our study is an important addition to existing research, as most EVT research is done primarily in terms of students in a classroom (Wigfield \& Eccles, 2000; Eccles et al., 1983; Wigfield, Tonks, \& Klauda, 2009), and not in terms of teacher motivation. Also, unlike our study in which we use a qualitative approach using the EVT model to analyze prospective teachers' (career switchers) teaching path, most of the existing research in this area consists of quantitative studies (i.e., Fokkens-Bruinsma \& Canrinus, 2012; Kilinc et al., 2012; Konig \& Rothland, 2012; Watt \& Richardson, 2012). The current study analyzes a collective instrumental case study, designed to illustrate unique differences and similarities in terms of teacher motivation and beliefs about teaching among participants. Qualitative data (pre-service teacher interviews) from this study were collected as part of a larger study (Thomson \& Palermo, 2018) investigating motivations and views about teaching. Ten pre-service teachers enrolled in a Master of Arts in Teaching (MAT) program with an Elementary Education focus were interviewed during their first year of study (Thomson \& Palermo, 2018). After all data was coded, three case studies were purposefully selected to illustrate unique stories about choosing the teaching career path in the current study. The following research questions were addressed:

1. In what ways are the three case study participants similar in their motivators for teaching and views about the teaching career? Do these participants share common motivators and beliefs about their chosen teaching path?

2. In what ways are the three case study participants different with respect to their motivations for teaching and their views about teaching?

\section{Methodology}

The current study is part of a larger phenomenological study (Thomson \& Palermo, 2018) investigating motivations and expectations about teaching of ten elementary pre-service teachers interviewed during their teacher preparation program. Data analysis in the current study includes a within-case analysis and then a cross-case analysis to compare and contrast three case studies (Molly, Molly, Tracey, and Mia, pseudonyms) using an EVT model. The three case studies have been chosen from the ten participants (in Thomson \& Palermo, 2018) with a purposeful maximal sampling approach, selecting thus case studies that seem to have the most to discuss and analyze in terms of findings (Creswell, 2007). Interviews consisted of 30 questions focused around teacher motivation, expectancies and beliefs about effective teachers, future plans, and coursework to prepare participants for teaching as a career. Sample questions can be seen in Appendix A.

\section{Results}

Results are discussed for the three case studies from an EVT approach, describing five major themes from participant's interviews: expectancies, attainment value, intrinsic value, utility value, and cost.

\subsection{Case Study 1: Molly}

Molly was a single 26-year-old student without children at the time of the original interview. Molly had previously received an undergraduate degree in athletic training, graduating with honors, but decided to teach because she enjoyed her position as a nanny so much, apart from the hours worked.

\subsubsection{Expectancies}

In terms of expectancies for the career, Molly stated that she hoped she would be a good teacher and fair: "I believe in say what you mean and mean what you say, so I hope that the children will have a respect for what I'm saying and they listen to me, but I don't have to be mean and forceful to get my point across." Molly hopes to have a classroom that feels like a team. Her perception of herself as a future teacher is that she will be very relatable to kids. She says, "...make my lessons things that children are going to want to do. And just, they're easy for them to understand, not using a lot of big words, and have...make things seem like they're on their level so that they can excel without really knowing that that's what they're doing." Molly wants to encourage students to do their best and to tell them that they are smart. She said she thinks she will use positive reinforcement to motivate students.

When asked about confidence to teach, Molly said she felt "pretty confident." She mentions nervousness about having to teach to the Common Core (recently introduced in the US) as part of the educational reform to improve education in classrooms: 
"The only thing that makes me a little nervous is that the things we are learning this year are for the [university] Standard and next year we're going to be teaching the Common Core; classroom-wise it's going to be a little different because kids are going to be moving even more and discussing even more and doing more research and free thought than they are now. So, I'm kind of concerned on how I'm going to manage that."

She also mentions that she knows she will need to improve with organization and time management when she actually becomes a teacher. However, early in her interview, she said that she thought she would be good at teaching, and again at the conclusion of her interview, she ends with: "Once I get used to it I think it will be a smooth transition; I'm sure I'll be stressed out the first week or two while I'm trying to figure out all the policies and practices that I need to do at my certain school. But other than that, other than just learning the rules and the guidelines, I'm not too concerned about it."

Molly seems to understand that there will be some challenges getting used to her new school when she eventually gets a job. She also seems to realize the challenges she will face with incorporating the new Common Core curriculum, but she remains confident that she will be a positive and effective teacher. Her expectancies do not seem too muddied with potentially difficult situations.

\subsubsection{Attainment Value}

Molly describes how she enjoyed working with elementary school children while she was in high school, and loving working with the kids she nannies for now. She said that nannying, combined with "having the experience in the classroom, has made [her] feel like it is something [she] would like to do." School experiences mentioned were that the fun activities in school helped her learn the most because the teacher did such a good job of making class fun that she didn't even realize she was learning, "Most of my public school I did have good teachers and I think they modeled a very professional way to teach. I felt comfortable around them."

Molly's belief is that an effective teacher "is someone who cares about her students just as much as she cares about herself." She mentions that a quality teacher is not looking to get tenure and summers off. Molly says, "I think a teacher needs to have calm qualities and that's about it."
Later in her interview, she mentioned that a good teacher treats all students equally and does not let stereotypes or favorites get in the way of teaching: "I believe that all the students should be treated equally. It's really hard not to do stereotypes and judging and picking favorites, but that's something I think all teachers need to work for. And most kids have the potential to success or actually all kids have the potential to succeed and I just want to treat them the best that I can and encourage them to do their best."

Molly places heavy emphasis on the importance of treating students equally and giving them a fun atmosphere in which to learn. She believes that a quality teacher will embrace these characteristics and almost 'trick' students into learning, just like her teachers did for her.

\subsubsection{Intrinsic Value}

Molly was influenced to choose teaching because of other friends who enjoy teaching. She described how she helped the children she was a nanny for with their homework and how it felt great to see the progress that they made. She says: "I work with an eight-year-old and a thirteen-year-old, so it's very different subject ranges, but they bring home their homework...the younger one struggled a lot with reading, I helped the older one with math. He was struggling in Algebra...once you find [a concept] that works, it's nice to see that the light really does go on; they actually get it and they can continue working successfully after that point."

Molly's personal fulfillment from helping these two children made her want to help other children, as well. She mentions using her own methods to help these particular children from her quote, since, in her own words, "Obviously I had no clue what I was doing, 'cause I didn't have any teaching classes yet." Even without teacher training, Molly knew she personally enjoyed figuring out ways to help a child understand a concept. When asked specifically how she came to the choice of deciding to teach, Molly answered: "What attracted me to teaching was that I loved tutoring the kids that I work with. Both of my parents work in the school system. I think it's fun; I was really nervous to go into it, at first when I was in college, because there are so many horrible stories about it: the government, the pay, and the parents. But I realized with any job there's going to be stuff like that. And all my friends that teach seem like they enjoy it and I think I will be good at it." 


\subsubsection{Utility Value}

In her interview, Molly did not mention much in regard to utility value; however, she did mention a couple of times in her interview ways in which she could fulfill a need in the position with character traits or her personality: "My friends who teach said that they really liked it and they thought I would be good at it; they know my personality and they said it would match well with the younger elementary school kids, and I agreed...I think the main thing that life experiences teach is the character traits needed for teaching, which are patience and understanding and empathy, and certain things like that." It appears that Molly thinks she has these ideal character traits herself, which helps solidify her confidence in her future career path.

\subsubsection{Cost}

Cost is mentioned in several ways in Molly's interview. She mentions at the beginning of the interview that her parents discouraged her from teaching "just because they are so fed up with all the politics of it." She also mentions how much of a responsibility it is to be a teacher, and that teachers don't get enough support from the administration because the administrators are also caught up in the politics of teaching: "I don't feel like teachers get enough support from the administration because they're trying to follow the politics of teaching, which don't really correlate with the purpose of teaching. So that's got to be hard, to be trying to teach your students, but your administration is telling you that you have to move on even if [the kids are] not getting it."

Another cost associated with the teaching career for Molly is literal monetary cost. She discusses finances: "Financially, I don't think it's so great at all. You're spending a lot of your money on materials. A lot of times you don't have parents who can help aid the classroom, so you're going to be spending money out of your own pocket, which you really don't have a lot of because, you know, you're not getting paid very much at all."

This literal cost of teaching is one of the things Molly realizes she may have to give up in order to fulfill her goal of becoming a teacher. Another cost mentioned by Molly is the way society views the career of teaching: "a lot of people view teachers as babysitters and a lot of people view teachers as complete idiots and a lot of people view teachers as very smart people. I don't think there really is a generalized society view."

Molly does not seem to think that there is a huge cost in the way society views the profession of teaching; she believes that society has many different views toward teaching as a career, so she does not seem to be worried about that cost of her goals. In terms of the costs being worthwhile, Molly lists several advantages of teaching that would make the costs bearable: "I feel like it's great hours, the classroom sizes are limited - I mean, I know they can get big - but they're not going to get too big, and that's going to help with teaching. A lot of schools have a lot of extra resources, which will also be helpful in teaching...[another advantage is] being on a hall, which I'm sure I'll be collaborating with a bunch of different teachers with different experience ranges who can give me different information that can help me further my career and reach my students the best way I can."

With her teaching program being worth the costs, Molly mentions that the reason she loves the program at her university so much is because a lot of other programs meet mostly online, and the one she was in is mostly in person. She says: "I liked that because it allows you to collaborate with your classmates and think of new ideas and promote critical thinking."

\subsection{Case Study 2: Tracey}

Tracey was, like Molly, a 26-year-old single woman with no children at the time of her interview. She had an undergraduate degree in journalism and mass communications and three years of experience working in retail and fundraising.

\subsubsection{Expectancies}

Tracey expects that her teaching will involve having a close relationship with her kids while keeping a professional line between them. She says, "I want to know my kids, I want to know their families, I want to know what's going on in their lives." She describes her perception of her future classroom as one that would seem a little bit like chaos. She sees herself giving a lot of hands-on activities and doing a lot of small group work: "I'm not the type that wants to get up and stand in front of my kids and lecture all day and have them sit quietly. I want them engaged in hands-on activity and doing a lot of small groups work. Working together a whole lot...collaboration 
I think is key...it's sort of organized chaos. I don't want it to be silent; I want them to feel free to talk to one another."

In addition to the types of activities that she feels she will ask students to complete, Tracey also describes that she expects she will be a very laid-back teacher: "I guess I'm a little bit more liberal in that respect, you know. I don't feel like I'm going to be super strict...they're going to know the boundaries, and they're going to know what it is that I expect of them. But I want them to be able to feel free to be kids at the same time and not just sit there like robots."

Tracey says that she hopes she will be happy teaching and that she thinks she will be. She also expects that it will be "the hardest job there is." She explains a lack of autonomy for teachers, saying: "As a career, [teaching] is always changing. I think, a lot of teachers I talk to feel like they finally have perfected their lessons and they've got this great unit and then the county or the state, they change the standards on them and they're not teaching that. So I think because it's always changing that, you know, its' a little bit of a disadvantage...I think my biggest concern is juggling everything that's expected of [me]...Especially, you know, with a lot of emphasis on EOGs and AYP [state standardized tests] ... So, I think that's going to be the struggle, just balancing all that other stuff with what you're really there to do, which is to teach the kids."

Finally, Tracey explains, like Molly, that she knows she will face challenges in her teaching career, but she feels confident that she can handle them. She explains: "I feel confident that I can do this. I mean, I recognize that it's going to be challenging and I recognize that I don't know everything. I think as I progress, I'm just going to be more and more confident in my ability to teach kids. And I think, you know, that in general I'm about ready to start student teaching. I am pretty confident."

\subsubsection{Attainment Value}

In terms of attainment, Tracey speaks of her love of working with children and how it shaped her goal of becoming a teacher: "I've always liked working with young kids. When I was in undergrad, I nannied for a family part time for years and I loved it. But somehow, I always sort of talked myself out of it...And I just kept thinking, what do I want to do with my life, and it always just kept coming back to working with kids... and really that's what motivated me to come back. Just, I love kids, I love working with them."
She mentions how when she was a nanny, she loved helping the kids with homework and projects. Tracey admits that being a nanny was probably the most critical influence on her decision to teach, saying how much she loved being in an environment with children. Tracey also mentions past teachers as an influence on her decision to teach, and how she has kept in touch with one teacher in particular. She says: "I've also kept in touch with a lot of my teachers that have meant a lot to me. I think they have made such an impact in my life and I would like to, you know, do the same for other kids. Specifically, my fourthgrade teacher and I are still in contact; I actually babysit her children right now and um, she's just been a great encouragement. So, I've grown up sort of around a lot of teachers, a lot of my mom's friends are teachers...I've sort of been in that environment my entire life."

Another piece of evidence for attainment value found in Tracey's interview was her experience in school growing up. She remembers being bored in middle school during lecture after lecture and decided she would be a different type of teacher. Further, Tracey goes on to describe the importance of being a good teacher to reach every student. She describes an effective teacher as one that knows the material and is willing to be a learner, as well. She also says that an effective teacher has to know his/her kids individually: "I think quality teaching has a lot to do with customizing your lessons to each individual child, making sure that every child's individual needs are met. And I think that that's obviously quite a challenge. Especially when you have a classroom full of 25 students. But I think the best...the best way to do that is through small groups... and then being able to pull small groups and work with kids one-on-on as best you can."

Tracey speaks of a quality teacher as realizing that sometimes "the kids know more than we do", and that a good teacher will always put the emphasis on her students. At the end of her interview, she reiterates, "I want to make a difference... And I think as a teacher, we have the opportunity to change the world. And that's why I'm in this." Tracey places a lot of attainment value on her choice to go into teaching. She wants to make a difference for students, loves working with students, and enjoys the fact that she'll have a chance to change the world.

\subsubsection{Intrinsic Value}

Tracey says that she thinks a major advantage of the career is changing the lives of the children that she teaches. 
She says: "Well, I think some of the advantages are just in an essence of what you do every day. You know, you really are changing the lives of the children that you teach. And you have an opportunity to make a difference in the life of a child and I think that, that in itself is the greatest reward out there."

Tracey thinks that the most rewarding part of her teaching job will be when she sees a child really get a concept and apply it. She mentions the light bulb going off in someone's head. She also mentions the personal reward of having students come back to visit and say that she has made a difference for them: "I think for me it's going to be that moment when a child gets it. When they finally, when that light that goes off and they're like, I get it. And then they start applying it and they use it. And I think that's going to be the most rewarding. I also think when they come back and visit you after having left your classroom, you know years, years ago and they come back, and they say, you know, you made a difference. I think that's going to be some of the most rewarding times."

\subsubsection{Utility Value}

Tracey's interview does not give a lot of evidence for the utility value she sees in the teaching career. She does not mention any personal ideal teaching qualities or characteristics other than saying what type of teacher she expects she will be, nor does she explain that she will be able to fill a need in the profession, other than to say that her methods courses have given her "practical solutions to everyday problems."

Tracey does believe that the teaching profession would provide utility value in the sense that it might aid in sustaining the life of someone who wanted to have a family. She explains, saying, "And I think, you know, for someone who does want to have a family and does want to have kids, being a teacher is nice, because you have the same holidays, you know; the same breaks that your children will have, you will have as well. And so, I think that is a definite advantage." Her intrinsic value does seem to be high, though, so perhaps for Tracey, gaining intrinsic value and happiness from teaching could help sustain her life or help her develop those ideal qualities in a teacher.

\subsubsection{Cost}

Tracey mentions many costs of teaching as a career. She says that she never realized how much teachers have to actually do that takes away from their normal lives. In fact, she mentions "juggling everything that's expected of them" as a cost for teachers and lists it as one of her greatest concerns about the profession: "I think it's probably one of the toughest jobs there is. They don't just teach anymore, there are so many other things that go into it. There's so much paperwork and there's so many county and state expectations, school expectations, managing parents, working with administration, and working with your teachers. Most teachers stay till six or seven at night, so I definitely think it's the hardest job there is."

Tracey says that she does feel like teaching is respected in general. She explains, "I feel like it's a respected job...I do feel like some people may say, 'Oh, well, they're not a doctor or a lawyer,' but I think in general people respect teachers." Tracey also mentions that although teaching is a societal respected career, it is a job that is very under paid, which is a cost when considering how many expectations teachers have placed on them. In this sense, Tracey does see that teachers are experiencing a 'cost' in terms of pay. However, Tracey feels that the pay is not enough of a cost to keep her from teaching: "I do think it's completely underpaid...especially with how much they [teachers] have to do every day... To me, that wasn't really a consideration. I think when I got out of college, I was kind of like, 'I want to make $\$ 50,000$ a year or I want to do this.' It was very focused financially and then when I got out, I realized, okay, I'm doing pretty well financially, but I'm not happy...I wish teachers were paid more, they deserve to be paid more, but again, that wasn't really something that I think much about." Tracey believes that the costs or sacrifices for getting her degree are worth it. She mentions classes like methods courses in math and social studies, a class in diversity, and says that these have all prepared her to teach better and that they have helped develop her content knowledge.

\subsection{Case Study 3: Mia}

Mia was a 34-year-old mother of three girls at the time of the interview. Her background in undergraduate study was in Psychology, with some law school and work after earning her Psychology degree. After natural disaster Hurricane Katrina relocated her family, Mia began substitute teaching and found great enjoyment in working with children in a classroom setting. 


\subsubsection{Expectancies}

Mia perceives herself as a "silly" teacher who uses humor to get to kids. She explains how her subbing experiences have helped shape this expectancy: "I know that when I'm subbing, I can be a little silly, so I tend to use humor a lot when I'm working with children. But I also tend to be a little strict. I know when I first started subbing, I had a lot of real high demands of the children and they didn't really like me very much. And I saw that I could be strict, and the kids wouldn't even mind if I was using humor, so I could use both and kids really would respond to that."

Mia also expects that along with being funny and strict, she will have a lot of technology use in her classroom. She speaks of several examples and mentions that other countries are also starting to use a lot of technology with students: "I know I like to bring a lot of technology into the classroom; I'm big on student blogs and things like that. I do see on Twitter that a lot of other countries are using internet sources...Wiki-ing, blogging, and kids are interacting with their classroom websites, so I like a lot of the technology stuff and I think that's important for the kids to learn, and so I want to bring that in."

Mia believes that she will use small groups in order to teach differentiated lessons. She describes that giving a lesson to the whole class leaves too many students out or leaves children behind others. She describes her expectancies: "Because kids learn at different levels and you have a huge range of kids in the class who are at different levels in the material and so I don't really like doing the whole group lessons. I used to think it would be impossible to do all small groups for everything. But my teacher that I have been observing this semester is able to do it; so that has given me a little bit of hope."

Emotions related to teaching for Mia are positive. She said, "I know there are going to be times when it's stressful...but overall I just think it's going to be an enjoyable experience." She expresses nervousness about not having a lot of autonomy or choice in her classroom and what/ how she wants to teach "I think the biggest drawback is lack of control over what and how you teach." Finally, in regards to confidence, Mia mentions that she feels prepared to teach the content, even though she knows she still has more to learn. She says: "I think that I could learn the basis of what I need to teach quickly in order to delve into those contents or subjects that I would need to teach, especially in science. I think I still need to learn to remember a lot of the science concepts, but I feel confident that when I grab a book or research, I'll be able to learn it quickly to teach the basics."

\subsubsection{Attainment Value}

Mia explains in her interview that she wants to make a difference from the strict classrooms she grew up in and allow students to have positive reinforcements and "happier schooling." She says of her childhood and teaching beliefs: "I don't like the strictness from when I was in elementary school... That just made me want to avoid school at that age. My later schooling wasn't as strict...I think that influenced me in the fact that I really don't like the negative reinforcements. I prefer to try to use positive reinforcements "cause it just makes for more happier schooling and I think it's more effective."

Mia describes effective teaching as being able to connect with each student. She said that with differentiation a teacher can reach each student and at their own pace. She thinks that an effective teacher doesn't necessarily have the best scores, but that the students are learning skills and information to use in the future. She also says that "as a teacher, you need to be constantly learning, and there are ways to get deeper in it." Towards the end of her interview, Mia repeats how much she enjoys working with children and suggests that she probably will still be teaching years from now: "I don't really see myself doing anything else at the moment, so I imagine I will still be teaching. I know I considered whether or not I would want to go back to college and become a college professor. But I think that from my experience, where I really enjoy working with the children themselves, I don't really see myself changing that."

\subsubsection{Intrinsic Value}

Mia describes that substitute teaching was a huge motivator for her and that teaching her own kids made an impact, as well: "I took a year off [from law] and I decided to give teaching a shot...so I became a substitute and I really enjoyed it. Teaching my own kids was a big factor. Some people would say I was obsessed with it, because I was teaching them pretty much from when they were born, and I really enjoyed doing that."

She also explains how her former job teaching a computer class to English Language Learners was very enjoyable for her, leading to her decision, as well as working with children in a preschool while she was in high 
school. When asked what the most crucial influence was on her decision to teach, Mia answered, "Just a strong desire to work with children. I find that I'm happiest when I'm around and working with kids as opposed to the different jobs I've had working with adults. I get a lot of pleasure around children and I do enjoy teaching."

Finally, when asked about how family or friends have shaped her decision to teach, Mia lists one particular friend who supported her decision. She also mentions that her family was pretty discouraging in her goal to become a teacher: "Family - I would pretty much say everyone was against it. My mother was very concerned about the pay. My husband still doesn't like it; he, as well, is concerned about the pay. And so I would say support from family, not so much. I have some friends who are teachers from New Orleans. One in particular was a close friend of mine and um, she's a teacher in New Orleans and really enjoys it and speaks highly of it and so that helps give some support to it, to know that...I just feel better knowing that I'm doing something I enjoy."

Mia believes that the greatest reward from teaching would be seeing the children grow intellectually. She said that when a kid "gets it" is a powerful feeling for her, even as a substitute teacher: "Even as a substitute there are opportunities when I'll go in a classroom and the teacher provided the material and the kids really don't get it and if I leave the classroom feeling like, 'Wow, I've only been with these kids for a day and they've actually learned something and they understand it now,' that's always a powerful feeling. And so, I think the most rewarding thing is watching the children learn something, and they really understand it."

\subsubsection{Utility Value}

In terms of utility value, Mia does see one important way that teaching can help sustain her life: it will give her a chance to be free when her children are free. She explains how much it burdened her to further her education while her children were young and in school, so she only ever went part-time: "I think while even though [law] was part time, it still pretty much took all my time and the fact that I had a nine-month-old was really hard emotionally. I knew I didn't want to work that much and not have the time with my children... although I know teachers work a lot, and they work long hours, they do get a lot of time to spend with their families as well, especially in the summers when the kids are off... and so I think that's a big influence - I know
I'm going to have time with my kids because their breaks coincide."

Along with fulfilling her need to be with her children, Mia also sees needs in the profession that she feels she can fulfill, including the use of technology in the classroom and the need for teachers to constantly be learning. She mentions studying other cultures' ways of teaching content and how she will continue to do that in her career. In addition to her thoughts on fueling the need for technology, Mia speaks about her passion for fulfilling the need in education of continuing to learn as a teacher, including learning about cross-cultural methods of teaching. Mia explains: "But in the math class something that was really inspiring was because of the way that other countries teach that are doing well...the teacher is never really finished studying. They have to, in other countries, they use a lot of time - they give the teachers a lot of time during the day to actually learn further in the academics of the material themselves. So, I like the whole looking at the way other countries do it that was taught in math. That was very inspiring."

Mia realizes that teaching will be useful to her in her life and feels that she can be instrumental as a teacher through her implementation of technology and her willingness to always continue to learn.

\subsubsection{Cost}

Costs of the profession mentioned in Mia's interview are low pay, a lack of autonomy, and getting moved from different grade levels or content areas. She mentions finances several times in her interview. Mia says early on in her interview, "Well, from high school I had wanted to be a teacher, and I had chosen against it because of the pay. And a lot of people were discouraging me from doing it, so it was mostly the pay."

She also mentions in her interview that her family and husband were against her choice due to the salary. Later in her interview, she mentions finances again, saying, "I did mention the financial. Although overall, I don't really think the financial is as bad as people tell me...I know if my husband wasn't bringing anything to the table and was laid off of work, we would seriously be struggling." During Mia's interview, however, she does mention that her happiness is worth the 'cost' of the low pay: "I just feel better knowing that I'm doing something I enjoy, even if 
I'm not getting the money that everyone seems to want me to get."

Ironically, Mia does not see time as a cost of teaching, because she feels that teaching will give her ample time to spend with her children since they will have the same breaks from school as she will. She found that time was a great cost in her previous jobs, with going to school and doing work in law and various other positions. The final drawback to the profession found in Mia's interview is a lack of autonomy for teachers. Mia mentions that a teacher can be moved very suddenly from a grade level or subject. Although there are some negative costs that Mia associates with teaching, she believes that her preparation program costs have been worthwhile; she says her program has done well to train her for the classroom.

\section{Discussion}

Several themes emerge from these case study participants' interviews. There is a common thread of a lack of control in the classroom, the politics of teaching, and low pay. Another trend is the intrinsic motivation for teaching - all three participants chosen stated that they want to teach because of personal enjoyment or making a difference in student lives. All three participants look forward to students finally understanding material - Tracey and Molly both mention the application of information, as well. Both Mia and Tracey mention individualized instruction and differentiation in quality teaching when speaking in terms of attainment value. Another similarity includes societal views on teachers - none of the participants seemed to feel a strong negative or positive view from society. Molly and Tracey specifically mention social status of the teaching career, while Mia does not mention it at all. Molly believes that society has a mixed view of teachers, with some respecting the career and others not respecting the career or thinking teachers are not very special or important. Tracey believes that as a whole, society respects teaching as a profession, even though society may place more importance on being a doctor or lawyer or similar position. Mia, when asked about her thoughts on teaching as a career, was probed to speak about social status but instead focused on financial aspects of the job, as well as how tough it is to accept all the constant changes in what a teacher must teach to students. This could be just an oversight on Mia's part, or it could suggest that social status is not important enough to her to mention.
Interestingly enough, none of the participants seem to have much to say about utility of the position. This would indicate that they saw a great usefulness for the profession in relation to their own lives, or that they saw how they could fill a need in the profession. In coding, utility value was not found abundantly in any of the three interviews: Molly speaks of how her friends believe she has the right personality to teach, Tracey explains that she believes teaching would provide utility for someone with a family and that having breaks would be useful, and Mia comes from both a family and worldly standpoint, explaining that, as Tracey suggested, time off from school will help her spend more time with her children. She also talks of being able to fill the need in the profession of staying on top of technology and exploring how other cultures do things in education. Perhaps the lack of usefulness explained by these three participants is made less important by the fact that they all three mention meaningful intrinsic value of the profession.

All three participants expressed in their expectancies that they want students to be free, to have individualized and small group work, independence, etc. Since all three participants come from the same teacher preparation program, it is difficult to tell if the education program has been a factor in shaping their ideas similarly about what kind of teachers they will be. All three participants also mention how hard the work of being a teacher is - dealing with parents, administrators, paper work, politics of teaching, long hours, etc. Molly is the only participant who mentions having to pay for materials and resources out of her own pocket - the other two participants do mention finances but do not give specific examples of financial situations as a teacher. Although all three participants mention altruistic reasons for going into teaching, they each have different influences for choosing to teach. Mia's family did not support her decision due to the pay; she was influenced by a teacher friend and by substitute teaching. Tracey was influenced positively by her experience as a nanny and from several old teachers, her family, and friends. Molly's family, like Mia's, also discouraged her from joining the school system, but she was influenced positively by friends who teach and from tutoring and babysitting students. It is noteworthy that both Molly and Tracey had similar influencing factors (e.g., babysitting) in wanting to become teachers and are both the same age, whereas Mia, whose influences were different, is almost ten years older and has had more life experiences. Mia's age could also potentially play a role in the fact that Mia's 
interview listed different 'costs' of the teaching career: she mentions mainly teacher pay and a lack of autonomy, and ironically differs in respect to Tracey's perceived costs of the career. Tracey mostly mentions time as a cost of teaching, in terms of losing time due to all of the expectations placed upon teachers. Mia seems to believe that she will have more precious and valuable time with her children if she teaches - perhaps because Tracey and Molly are not in a family mode at their age of 26, they do not see this time off from school to be as important as Mia does, since they may have no one precious to them to share the school breaks with.

Another interesting theme is that both Tracey and Mia specifically mention a drawback to the teaching career in terms of having a grade or subject changed after getting comfortable with one's subject area or grade level and lesson plans. Molly mentions changes like state standards changing and being nervous about the common core, but she does not specifically mention the type of change in situation that both Tracey and Mia do - she just mentions the politics of teaching in terms of a lack of administrative support.

Finally, when asked if they plan on staying in the profession, both Molly and Mia mention that they want to stay in the profession until retiring. However, they both also mention that they have considered going back to school for a doctoral degree or becoming a college professor. Tracey says that she wants to stay in education in some way, whether she's in the classroom or not. She mentions possibly becoming involved in school politics or becoming a school administrator. So, although all three participants have different end goal possibilities, they all do seem determined to at least stay in the field of education. Molly, Tracey, and Mia all echo what research says on teacher motivation - they all have expressed a need for personal fulfillment, a desire to give back to the community, and a joy for working with children. All three participants also seem to echo the research that states teachers are not compensated enough for all they have to do, and that teachers see a lack of administrative support and educational politics as a drawback to the profession.

Though some research has found that a commonality among teachers joining the profession is job security and benefits (Backes \& Burns, 2012; Ramirez, 2010), Molly, Tracey, and Mia do not seem to be in agreement with this notion. In fact, Mia even mentions in her interview that previously she would have mentioned job stability as an advantage of the profession, but now she has heard more and more of veteran teachers being laid off. Another difference between research findings and the three participants of this case study is that Molly, Tracey, and Mia all have a pretty neutral view of how teachers are viewed in society. They do not seem to see the lack of respect that many research reports have discussed.

These similarities and differences show the stillimportant need for even more research in the areas of teacher motivation and retention. Individualized and specific studies, as well as broad and general teacher studies, must be conducted in very specific conditions to get at the heart of reasons for motivation. For instance, the findings of these three case study participants show that there are many similarities and differences among them and what much research reports - and although these are just three women being compared to thousands of other participants, one wonders what data would be found with more in-depth case studies and qualitative research on teacher motivation and satisfaction.

Limitations of this study include limited data in terms of gender, thus the need to include more male teachers in the study. All of the original interviews for this study were with female pre-service teachers. Future research might include stages of the family life cycle as an important factor to study in terms of teacher motivation. Research findings could help teacher preparation programs become more in tune with their students and more research should examine why people are choosing not to teach. Such research could lead to gains in the education field in terms of teacher training, recruitment, and retention.

\section{Authors note:}

Dr. Margareta M. Thomson, Ph.D., obtained her doctoral degree (Ph.D.) in Educational Psychology and Learning Systems at Florida State University and currently is an Associate Professor of Educational Psychology at North Carolina State University. Her research investigates teachers' motivations, expectations, values and classroom practices using primarily mixed-methods approaches.

Julia McClannon, M.S., obtained her master's degree (M.S) in Educational Psychology at North Carolina State University. She is currently teaching at Fuquay-Varina High School in North Carolina. Her research focus is on teacher burn-out, well-being and motivations. 


\section{References}

Ashiedu, J.A. \& Scott-Ladd, B.D. (2012). Understanding teacher attraction and retention drivers: addressing teacher shortages. Australian Journal of Teacher Education, 37(11), 17-35.

http://dx.doi.org/10.14221/ajte.2012v37n11.1.

Backes, C., \& Burns, J. Z. (2008). New career-technical teachers - what gets them, and why is it important to know? Career motivations of trade and industrial healthcare science second-career teachers. Journal of Industrial Teacher Education, 45(1), 100-112.

Bandura, A. (1997). Self-efficacy: The exercise of control. New York, NY, US: W H Freeman/Times Books/ Henry Holt \& Co.

Curtis, C. (2012). Why do they choose to teach - and why do they leave? A study of middle school and high school mathematics teachers. Education, 132(4), 779-788.

Creswell, J.W. (2007). Qualitative Inquiry and Research Design ( $2^{\text {nd }}$ ed.). Thousand Oaks, California: Sage Publications, Inc.

Eccles, J.S., Adler, T.F., Futterman, R., Goff, S.B., Kaczala, C.M., Meece, J.L., \& Midgley, C. (1983). Expectancies, values, and academic behaviors. In J. T. Spence (Ed.), Nebraska Symposium on Motivation (Vol. 32, pp. 97-132). Lincoln, NE: Univ. of Nebraska Press.

Fokkens-Bruinsma, M. \& Canrinus, E.T. (2012). The factors influencing teaching (FIT)-choice scale in a Dutch teacher education program. Asia-Pacific Journal of Teacher Education, 40(3), 249-269. https://doi.org/10.1080/1359866X.2012.700043.

Kilinc, A., Watt, H.M.G., Richardson, \& P.W. (2012). Factors influencing teaching choice in Turkey. Asia-Pacific Journal of Teacher Education, 40(3), 199-226. https://doi.org/10.1080/1359866X.2012.700048.

Konig, J., \& Rothland, M. (2012). Motivations for choosing teaching as a career: effects on general pedagogical knowledge during initial teacher education. Asia-Pacific Journal of Teacher Education, 40(3), 289-315. https://doi.org/10.1080/1359866X.2012.700045.

Manuel, J., \& Hughes, J. (2006). 'It has always been my dream': exploring pre-service teachers' motivations for choosing to teach. Teacher Development: An international journal of teachers' professional development, 10(1), 5-24.

Ramirez, A.Y. (2010). Why teach? Multicultural Education, 17(3), 29-35.

Richardson, P.W., \& Watt, H.M.G. (2005). 'I've decided to become a teacher': influences on career change. Teaching and Teacher Education, 21, 475-489.

Richardson, P.W., \& Watt, H.M.G. (2006). Who chooses teaching and why? Profiling characteristics and motivations across three Australian universities. Asia-Pacific Journal of Teacher Education, 34(1), 27-56.

Schutz, P.A., Crowder, K.C., \& White, V.E. (2001). The development of a goal to become a teacher. Journal of Educational Psychology, 93(2), 299-308.

Thomson, M.M. (2018). Identifying and Examining Motivational Profiles: Distinct Typologies with Blended Motives. In M. Gill (Ed.), SAGE Research Methods Psychology (pp. 1-13). London, UK: Sage Publications. http://dx.doi.org/10.4135/9781526449177.

Thomson, M.M., \& Palermo, C. (2018). Using an ExpectancyValue Model to understand teaching motivation among nontraditional preservice teachers: A phenomenological study approach. Action in Teacher Education, 40 (2),151168. https://doi.org/10.1080/01626620.2018.1424050.

Thomson, M.M., \& Palermo, C. (2014). Preservice teachers' understanding of their professional goal: Case studies from three different typologies. Teaching and Teacher Education, 44, 56-68. https://doi.org/10.1016/j.tate.2014.08.002.

Thomson, M.M., \& McIntyre, E. (2013). Teachers' professional goals: An examination of different teachers' typologies with respect to motivations and beliefs about teaching. Teacher Development, 17(4),409-430. https://doi.org/10.1080/13664530.2013.804001.

Watt, H.M.G., \& Richardson, P. (2008). Motivations, perceptions, and aspirations concerning teaching as a career for different types of beginning teachers. Learning and Instruction, 18, 408-428.

Watt, H.M.G., \& Richardson, P. (2007). Motivational factors influencing teaching as a career choice: development and validation of the FIT-choice scale. The Journal of Experimental Education, 75(3), 167-202.

Watt, H.M.G. \& Richardson, P.W. (2012). An introduction to teaching motivations in different countries: comparisons using the FIT-Choice scale. Asia-Pacific Journal of Teacher Education, 40(3), 185-197. https://doi.org/10.1080/1359866X.2012.700049.

Watt, H.M.G., Richardson, P.W., Klusmann, U., Kunter, M., Beyeer, B., Trautwein, U., \& Baumert, J. (2012). Motivations for choosing teaching as a career: an international comparison using the FIT-choice scale. Teaching and Teacher Education, 28, 791-805.

Wigfield, A.L., \& Eccles, J.S. (2000). Expectancy-value theory of achievement motivation. Contemporary Educational Psychology, 25, 68-81. https://doi.org/10.1016/j.tate.2012.03.003.

Wigfield, A., Tonks, S., \& Klauda, S.L. (2009). Expectancyvalue theory. In Wentzel, K.R. \& Wigfield, A. (Eds.), Handbook of Motivation at School (55-70). New York, NY: Routledge. 